\title{
Organization Citizenship Behaviour and Performance of Academic Staff of Selected Tertiary Institutions in Lagos State
}

\author{
Olubayo Thomas OLAJIDE ${ }^{\star}$
}

\begin{tabular}{l}
\hline \multicolumn{1}{c}{ A R T I C L E I N F O } \\
\hline Article history: \\
Accepted June 2020 \\
Available online August 2020 \\
\hline JEL Classification \\
M22 \\
Keywords: \\
Courtesy, Altruism, Sportsmanship, \\
Performance, Organisation \\
Citizenship Behaviour
\end{tabular}

\begin{abstract}
A B S T R A C T
The managerial practices in most tertiary institutions in Nigeria have resulted to striking action on the part of the different union groups in Nigeria campuses. This has discouraged employee behaviours towards their responsibilities. The study examined organization citizenship behaviour (OCB) and performance of academic staff of selected tertiary institutions in Lagos State. The study adopted survey research design as well as simple and stratified sampling methods. It is demonstrated from the regression analysis that courtesy, altruism as well as sportsmanship have positive and significant contribution on staff performance. The study concluded that there is a significant effect of organization citizenship behaviour (OCB) on the performance of employee in tertiary institutions in Lagos State. The study suggested that the management of tertiary institutions in Lagos State and Nigeria as a whole should formulate policies and/or adopt practices that will encourage organization citizenship behaviour for better performance.
\end{abstract}

(C) 2020 EAI. All rights reserved.

\section{Introduction}

Globalisation process has redefined business activities in today's world. The cross-border opportunities to both human, material and financial resources have informed organization to redefine their mission and vision in line with what can be achieved by the behavior displayed by the employees in their respective organisations. Thus, employee behaviour is to a larger extent determinant factor in accomplishing mission and vision of an organization. Organisations reliance on the employees is a fundamental because the employees are the factors that control, direct and utilize organisational resources in accordance with the directives of the management

Iskandar, Ahmad and Martua (2014) stated that performance of the employees goes a long way to determine the success of the organization. According to Shahrouz, Mahdi and Marjan (2016) organizations that want to be successful need employees that will be committed beyond the organisations expectation. There is no how employee could be performing in the organisation without offering assistance or exhibiting behaviour to help one another directly or indirectly towards achieving organizational goals (Robbin, 2013). More importantly today when organisations are adopting lean employment strategy, those that are in the employment need to display more commitment to the success of the organization if not, they may be shown the way out. Thus, the idea of displaying more commitment by the employees in the organization is referred to as organization citizenship behavior (OCB). In other word, OCB is a set of voluntary workplace behavior over and above ones basic job assignments. Johanger, Akbar and Hag (2004) described it as behaviors that go beyond the call of duty.

Organisational citizenship behavior (OCB) as a concept, has caught the interest of researchers since its introduction by Organ in 1988, and its study across the globe is increasing year by year. The study of OCB over the years has brought about some research fruits and positive impact on organizational performance. It has been established in the literature that OCB can improve productivity of the employees, enhances harmony and communication between or among the employees in an organization (Shahrouz et al. 2016).

The rate of errors that could be made by the employees could also reduce via OCB because there will be full commitment through adequate communication. In the opinion of Shahrouz et al (2016), OCB influences organizational inner factors such as job satisfaction, employee commitment, organizational atmosphere which lead to the improvement in the performance of the employee. Cohen and Vigoda (2000) asserted that OCB enhances productivity of both the employee and management. It helps the managem ent to effectively utilize and maintain the resources of the organization. 
Organizational citizenship behavior makes organization to have employees who are committed (Shahrouz et al. 2016). According to Shahrouz et al. (2016), Zeb and Asia (2016) self-sacrifice, dutifulness and patience are OCB factors that reduce employee turnover and absenteeism and thus overall enhancement in the performance of the organization to gain competitive advantage in the market. OCB comes in a variety of forms such as loyalty, helping others, compliance, benefit etc where employees are willing to contribute their efforts and abilities to the organizations even though that is not officially required from them' (Mohammad, Saima \& Farjana, 2016) and Norasherin, Rohaida, Mozhdeh, Siti and Nor (2016) noted that it most occur at the organisation individual.

Social an economic life development is among the functions of tertiary institutions and it is very fundamental. The notable tertiary institutions are the universities, polytechnics and colleges of educations. According to Serife (2016), tertiary institutions center on creation of knowledge and transmission of knowledge through teaching and research processes. The tertiary institutions cannot carry out the dual core functions without the academic staff. But recent development in most government owned tertiary institutions have shown that there is frequent industrial strike of which it does not exclude the academic staff of these institutions. In fact the academic staff of the tertiary institutions are at the nerve center of creation and transmission of knowledge. This continuous and incessant strike have seriously affected the behavior of the academic staff. It has in fact affected the eagerness of the staff to perform statutory duties not to talk of voluntary extra duty that is out of their job assignments.

Yet, the informal attitude and behavior of the academic staff in helping one another to perform is very important. Despite the fact that literature has confirmed positive relationship between OCB and organizational performance, this has not in the academic environment.

Ejo-Orusa, Gabriel, and Henry (2018) posited that OCB influenced the corporate performance of telecommunication firms in Nigeria. Nawaz and Gomes (2018) posited that OCB has positive impact on team performance among manufacturing firms. While Lelei, Chepkwony and Ambrose (2015) stated that OCB aids in task accomplishment and thereby enhances performance of banking employees in Kenya. All these studies were done in different industries much focus has not been given to how it will affect the performance in the educational sector especially the tertiary institutions that are the center where leaders of tomorrow are being raised.

This study investigates organizational citizenship behavior and academic staff performance in selected tertiary institutions in Lagos State. Other objectives that this study wants to achieve are to;

i. examine the effect of courtesy on the performance of academic staff of selected tertiary institution in Lagos State

ii. determine the influence of altruism in academic staff performance of selected tertiary institution in Lagos State

iii. identify the effect of sportsmanship on academic staff performance of selected tertiary institutions in Lagos State

\section{Literature review}

\section{Organisational Citizenship Behaviour and Employee Performance}

Itiola, Odebiyi, and Alabi (2014) conceptualized organisational citizenship behaviour as positive behavior and eagerness to exercise drive for the organizational success. Organisational citizenship behavior is seen as the employee extra conduct exhibit in meeting responsibilities within the organisation aside from the assigned normal responsibilities to the employee (Lelei et al 2015). OCB is the positive behavior of the employee that has direct effect on the development of the organization (Poncheri 2006). It describes the actions of employees to act further from the prerequisite requirements of their own function (Hardiman, Hendra \& Muhammad, 2019). Ejo-Orusa et al. (2018) stated that OCB is the optional behaviour of an individual that is not explicitly or directly acknowledged by formal compensation system but promote the effectiveness of the organization operations. To Meor, Sabitha and Nurul (2019), OCB is the behavior in the organization that goes beyond the formal expectations of function designated to the employees and is very vital to the organisational growth and survival. Shahrouz et al (2016); Norasherin et al. (2016) shared the thoughts of Oregon that OCB is the mindfulness and all-encompassing behavior of an employee which is not recognized by the employer or management for reward purposes. Thus, any behavior that is officially recognized is not OCB. OCB is seen as the sum of behaviors in the firm which formal reward system does not recognize or identify but beneficial to the overall effectiveness of the organization.

OCB is the behavior that has no formal backing and which aid in achieving organizational goals. Thus, it is the voluntary behavior of an employee in helping the organizational goals and objectives to be achieved. According to Olowookere, Adejuwon and Godwyns (2015); Haque, Khatibi and Karim (2011), the benefits of organizational citizenship behaviour (OCB) is enjoyed by the organisation itself as well as the employees. OCB improves an employee ways of contributing his quota to the organisation's accomplishment. Therefore Organisational citizenship behaviors enhance and influence the effectiveness in the performance of the employee and that of the management (Norasherin et al. 2016). According to Organ, Podsakoff, and MacKenzie (2006), OCB enables organization to adapt to environmental changes, improves organizations 
ability to attract and retain the best people and obtain stability of organizational performance and organizational effectiveness by creating social capital. The performance of the employee is a sign of effectiveness in the use of the resources that the organization posses. Iskandar, Ahmad and Martua (2014) opined that the performance of the employee could be in terms of quality, quantity, knowledge or creativity of employee towards the accomplishment of stated goals by the management in the tasks assign to the employees for a particular period. Ejo-Orusa et al. (2018); Shahrouz et al. (2016); Norasherin (2015) asserted that OCB makes employee to be effective in performing the task assigned to them by the management

\section{Organisational Citizenship Behaviour Dimensions and Employee performance}

OCB can be exhibited in many forms and these forms of different OCB have been identified as its components or dimensions. According to Norasherin et al (2016); Zeb and Asia (2016); Yen \& Niehoff (2004); Konovsky and Organ (1996), altruism, courtesy, sportsmanship, civic virtue, and generalized compliance are the components or forms of OCB. In the case of Ejo-Orusa et al. (2018), the OCB measures adopted are altruism, courtesy, sportsmanship, and civic virtue. Thus, altruism, courtesy, and sportsmanship are adopted as the component of OCB in order to achieve its objectives.

Courtesy involves consultation with other employees in the organization before taking a decision or an action. It deals with considering the likely effects of an action on other individual in the organisation if such action is taking. According to Zeb and Asia (2016), the purpose of courtesy as a component of OCB is to avoid work-related problems from happening and disturbing the operations of the organization. In the view of Norasherin et al (2016), courtesy is to prevent problems with other employees and to avoid the rights of other employees being abused in the organization. Mohammad et al. (2011) asserted that one of the behavior related to courtesy is alerting other employee on the change in their assigned tasks that may affect their effectiveness or performance. By courtesy, assistance is being giving one employee by another in order to enhance their performance. The changes that Mohammad et al. (2011) talked about could be in techniques of executing the assigned task(s), the changed rule(s) as well as the new or modern technology devices that could help in implementing the task as it is required by management. Ejo-Orusa et al (2018) found positive relationship between courtesy and organizational performance- profitability and market share. Shahrouz et al (2016) indicated that courtesy is among the most OCB displayed in Iranian gas organisations. Itiola et al. (2014) found that courtesy does not significantly influenced job satisfaction among Osun State tertiary institutions non-academic staff. Serife (2016) demonstrated that courtesy is not a common practice of OCB among academic staff in Cyprus. Lelei et al. (2015) depicted a positive and significant effect of courtesy on bank employees' performance in Kenya. The extent which courtesy affects Lagos tertiary institutions academic staff performance becomes an issue of interest. Thus, the hypothesis is stated to determine extent of relationship between courtesy and performance of academic staff in selected tertiary institutions in Lagos State

\section{$\mathbf{H}_{0}$ : Courtesy does not significantly affect performance of academic staff of selected tertiary} institutions in Lagos State

Another dimension of OCB is altruism. Altruism is referred to as the voluntary actions of employees in the organisations that help another employee in overcoming a particular challenge or solving a problem. Norasherin et al.(2016); Organ, (1997) see altruism as the helpfulness of an employee to another employee in the same organization. Thus, altruism simply implies assisting fellow employees or the employers in achieving the goals of the organisation. Olowokere et al (2015) stated that altruism means helping particular person in an organization. Zeb and Asia (2016) expressed that altruism is that additional role an employee plays in the organization to help others on a specific task. The authors believed that altruism influences the image of the organization. Thus altruism behaviour aids in making employee to carry out their duties effectively. This is because there is another employee that is willingly ready to offer help for his/her coworker to excel in executing the assigned task(s).

The study of Francis (2012) revealed that demographic factors such as age, gender, level of education etc affect altruism behaviour among employee in Oil industry in Nigeria. Turek (2015) also revealed that human resource practices enhances OCB component like altruism. Ejo-Orusa et al (2018); Shahrouz et al (2016) found positive relationship between altruism and organizational performance- profitability and market share. Itiola et al.(2014) indicated that there is a positive effect of altruism on job satisfaction but no significant effect on performance of administrative staff of Osun State owned tertiary institutions. Nyarieko, Namusonge and Iravo (2017) found that altruism has positive and significant correlation with employee performance in Kenyan public university. The mixed outcomes call for further investigation onto the possible effect of altruism on employee performance in other clime. Thus: the study hypothesized that

$\mathrm{H}_{0}$ : Altruism does not significantly influence the performance of academic staff of selected tertiary institutions in Lagos State

Sportsmanship, another component of OCB is the employee behavior that demonstrates tolerance of less than ideal environments without complaining (Norasherin et al. 2016). According to Ejo-Orusa et al. (2018), sportsmanship entails creation of little complaint process within an organization and having a pleasing environment for satisfaction of job and compassion for the job. To Zeb and Asia (2016), 
sportsmanship spirit behavior does not allow employees to complain about insignificant issues or matters in the organization. The employees are used to conduct of not complaining about matters that are unimportant (Norasherin et al. 2016). Sportsmanship is an act of tolerating the unavoidable inconveniences associated with the job that an employee is to do. Sportsmanship behaviour is the non-complaining conduct of an employee when encountering unnecessary challenges in the process of performing his responsibilities (Olowookere et al., 2015).

Ejo-Orusa et al (2018) stated that sportsmanship increases employee affective commitment on the job and to the organisation. Lo, Ramayah and Kuel (2006) posited that a good sportsmanship could lift employees' determination and morale in the process of executing the tasks assigned to them. The works of Ejo-Orusa et al (2018); Zeb and Asia (2016); Olowokere et al (2015); Tanaka (2013) identified that sportsmanship contributes highly to organizational success. Itiola et al. (2014) found insignificant effect of sportsmanship on non-academic staff of tertiary institutions in Osun State, Nigeria. Fatimah, Amiraa and Halim (2011) findings indicated that sportsmanship did not contribute significantly to job satisfaction. Olowookere et al. (2015) concluded that adequate attention has not been given to sportsmanship behavior as component of OCB in the literature. Thus, the uncertainty that surrounds the possible effect of sportsmanship on employee performance calls for further investigation which leads this study to another hypothesis.

$\mathrm{H}_{0}$ : Sportsmanship does not have significant influence on the performance of academic staff of selected tertiary institutions in Lagos State

\section{Research methods}

Survey research design is utilised to assist in achieving the study objectives. The population of the study is the academic staff in the selected tertiary institutions in Lagos State and the tertiary institutions are Lagos State University (LASU), Yaba College of Technology (YABATECH) and Adeniran Ogunsanya College of Education (AOCED) owned by both Federal Government and Lagos State government. The tertiary institutions were randomly selected. Thus, one university, one polytechnic and one college of education were selected. The number of academic staff in the selected tertiary institutions is 878, 813 and 235 for LASU, YABATECH and AOCED respectively which makes the population size for the study to be 1926. A multistage sampling technique- stratified sampling and simple random sampling techniques were adopted. The sample size of this study was determined using Taro Yamane and Cochran was employed for proportionate allocation of the sample size.

Taro Yamane formula:

$$
n=\frac{N}{1+N(e)^{2}}
$$

Where

$$
\begin{aligned}
& \mathrm{n} \quad=\quad \text { Sample size } \\
& \mathrm{N} \quad=\quad \text { Population of the study } \\
& \mathrm{e} \quad=\quad \text { precision of sampling error (0.05) } \\
& \begin{array}{c}
n=\frac{1926}{1+1926(0.05)^{2}} \\
n=\frac{1926}{1+1926(0.0025)} \\
n=\frac{1926}{1+4.815} \\
n=\frac{1926}{5.815}
\end{array} \\
& n=331
\end{aligned}
$$

In order to get the sample for each tertiary institution, proportionate sample sizeformular was employed because of the variance in the population size of the selected tertiary institutions.

Therefore the following formula illustrated the stratification and allocation of sample sizes to individual unit organizations within the entire population based on proportions: 


$$
C n=\frac{C N}{N} * \frac{n}{1}
$$

Where $\mathrm{Cn}=$ Estimated participant unit allocation per tertiary institution

$\mathrm{CN}=$ Population per tertiary institution

$\mathrm{N}=$ Total population of the study

$\mathrm{n}=$ Sample size of the study

LASU

$$
\begin{aligned}
& C n=\frac{878}{1926} * 331 \\
& C n=0.46 * 331=151
\end{aligned}
$$

\section{YABATECH}

$$
C n=\frac{813}{1926} * 331
$$

$C n=0.42 * 331=140$

\section{AOCED}

$C n=\frac{235}{1926} * 331$

$C n=0.12 * 331=40$

Table 1. Proportionate distribution of sample size amongst the selected Tertiary Institutions

\begin{tabular}{|l|l|l|l|}
\hline S/N & Tertiary Institutions & N & Ss \\
\hline & Lagos State University (LASU) & 878 & 151 \\
\hline & Yaba College of Technology (YABATECH) & 813 & 140 \\
\hline & AdeniranOgunsanya College of Education (AOCED) & 235 & 40 \\
\hline & Total & $\mathbf{1 9 2 6}$ & $\mathbf{3 3 1}$ \\
\hline
\end{tabular}

The method and source of data collection for this study is primary data through questionnaire as the research instrument. The questionnaire was a closed ended questionnaire and the respondents responses were ranked from strongly agree, agree, fairly agree, fairly disagree, disagree to strongly disagree. The questionnaire was divided into two sections. One section covered the bio-data details of the respondents and the second section covered the questions on variables employed in the study. This study adopted the measurement scale of Lelei et al (2015) on altruism, courtesy, and employee performance. And the measurement scale of sportsmanship of Nyarieko, Namusonge and Iravo (2017) were also adapted. Cronbach Alpha test and Kaiser-Meyer-Olkin (KMO) were used to test the internal consistency and the validity of the data obtained from the respondents. Descriptive analysis and regression analyse were employed to analysis the data.

\section{Data analysis, interpretation and discussions of findings Descriptive Statistics}

Table 1. Descriptive Statistics for the variables

$\begin{array}{lcccc} & \text { Performance } & \text { Altruism } & \text { Courtesy } & \text { Sportsmanship } \\ \text { Mean } & 5.291952 & 5.044542 & 5.199402 & 4.670837 \\ \text { Median } & 5.430000 & 5.140000 & 5.290000 & 4.710000 \\ \text { Maximum } & 6.000000 & 6.000000 & 6.000000 & 6.000000 \\ \text { Minimum } & 3.000000 & 3.000000 & 3.140000 & 2.860000 \\ \text { Std. Dev. } & 0.530170 & 0.590522 & 0.579023 & 0.708691 \\ \text { Skewness } & -1.096643 & -0.397419 & -0.705671 & -0.228414 \\ \text { Kurtosis } & 4.864355 & 3.011418 & 3.499235 & 2.245465 \\ & & & & \\ \text { Jarque-Bera } & 86.66114 & 6.608588 & 23.43838 & 8.136743 \\ \text { Probability } & 0.000000 & 0.036725 & 0.000008 & 0.017105 \\ \text { Sum } & 1328.280 & 1266.180 & 1305.050 & 1172.380 \\ \text { Sum Sq. Dev. } & 70.26994 & 87.17902 & 83.81681 & 125.5607 \\ \text { Observations } & 251 & 251 & & 251\end{array}$

\section{Interpretation}

Table 1 showed that among the independent variables-altruism, courtesy and sportsmanship, courtesy has the highest mean value of 5.199402 with the smallest value of standard deviation 0.579023 and the average value of the dependent variable-employee performance is considerably high. In the same vein, the normality of the data through skewness and kurtosis showed that the data are negatively skewed. The kurtosis values revealed that all the data have positive values. This indicated that the values of the variables exhibit flatness at the surface of the distribution and it is thus platykurtic that is there is normality in the data of the study 


\section{Unit Root Test}

\begin{tabular}{|c|c|c|c|c|c|}
\hline \multirow{2}{*}{\multicolumn{2}{|c|}{ Variables }} & \multicolumn{4}{|c|}{ Table 2: Unit Root Tests } \\
\hline & & ADF & & Unit I & erence \\
\hline Courtesy & & -13.14 & & -3.43 & Stationary \\
\hline Altruism & & -11.24 & & -3.42 & Stationary \\
\hline Sportsmanship & & -9.84 & & -3.42 & Stationary \\
\hline Employee Performance & -10.62 & & -3.42 & & ary \\
\hline
\end{tabular}

Source: Researchers' Computation, 2019

Table 2 showed the unit root test of the variables. Augmented Dickey Fuller (ADF) was employed to test the stationary of the variables. The variables were tested at first difference. The results indicated that all the data for the variables are stabilise. For a variable to be stationary the absolute ADF statistic value should be greater than the critical values given at various percentage levels ignoring the sign

Table 3: Correlation Matrix

\begin{tabular}{ccccc} 
& Performance & Altruism & Courtesy & Sportsmanship \\
Performance & 1.000000 & 0.381722 & 0.426704 & 0.457468 \\
Altruism & 0.381722 & 1.000000 & 0.708007 & 0.486675 \\
Courtesy & 0.426704 & 0.708007 & 1.000000 & 0.420410 \\
Sportsmanshi & & & & \\
p & 0.457468 & 0.486675 & 0.420410 & 1.000000 \\
& \multicolumn{2}{c}{ Source: Researchers'Computation, 2019} &
\end{tabular}

\section{Interpretation}

The above table 3 showed the correlation matrix among the variables of this study. It is shown that there is positive relationship among the variables of the study. Altruism, courtesy and sportsmanship have positive association with performance by $0.381722 ; 0.426704$ and 0.457468 respectively. The table further showed that the variables have positive correlation among themselves. There is positive relationship among the variables employed in the study

\section{Test of Hypotheses}

Hypothesis one: There is no significant effect of courtesy on the performance of academic staff of selected tertiary institutions in Lagos State

Dependent Variable: Performance

Method: Least Squares

Included observations: 251

\begin{tabular}{lrlrr}
\hline \hline \multicolumn{1}{c}{ Variable } & Coefficient & Std. Error & t-Statistic & Prob. \\
\hline \multicolumn{1}{c}{ C } & 3.260535 & 0.274533 & 11.87664 & 0.0000 \\
\multicolumn{1}{c}{ Courtesy } & 0.390702 & 0.052478 & 7.445083 & 0.0000 \\
\hline \hline R-squared & 0.182076 & Mean dependent var & 5.291952 \\
Adjusted R-squared & 0.178791 & S.D. dependent var & 0.530170 \\
S.E. of regression & 0.480443 & Akaike info criterion & 1.379719 \\
Sum squared resid & 57.47547 & Schwarz criterion & 1.407810 \\
Log likelihood & -171.1547 & Hannan-Quinn criter. & 1.391023 \\
F-statistic & 55.42927 & Durbin-Watson stat & 1.574784 \\
Prob(F-statistic) & 0.000000 & & \\
\hline \hline
\end{tabular}

\section{Interpretation}

Source: Researchers' Computation, 2019

From the above results, the R-squared which is the coefficient of determination showed that $18.2 \%$ of the changes in academic staff performance are caused by courtesy while the remaining percentage are caused by other variables that are not taking into consideration in the study. The findings revealed that there is positive and significant effect of courtesy on the performance of academic staff in Lagos State $(\beta=0.390702$, $\mathrm{t}=7.4450, \mathrm{p}$-value $=.000)$ 
Hypothesis two: Altruism does not have significant influence on the performance of academic staff of selected tertiary institutions in Lagos State

Dependent Variable: Performance

Method: Least Squares

Included observations: 251

\begin{tabular}{lrlll}
\hline \hline \multicolumn{1}{c}{ Variable } & Coefficient & Std. Error & t-Statistic & Prob. \\
\hline \hline \multicolumn{1}{c}{ C } & 3.563140 & 0.267083 & 13.34093 & 0.0000 \\
\multicolumn{1}{c}{ Altruism } & 0.342709 & 0.052587 & 6.516955 & 0.0000 \\
\hline \hline R-squared & 0.145712 & Mean dependent var & 5.291952 \\
Adjusted R-squared & 0.142281 & S.D. dependent var & 0.530170 \\
S.E. of regression & 0.491007 & Akaike info criterion & 1.423218 \\
Sum squared resid & 60.03079 & Schwarz criterion & 1.451309 \\
Log likelihood & -176.6139 & Hannan-Quinn criter. & 1.434523 \\
F-statistic & 42.47070 & Durbin-Watson stat & 1.548764 \\
Prob(F-statistic) & 0.000000 & & \\
\hline \hline
\end{tabular}

The results for this hypothesis that altruism does not have significant influence on the performance of academic staff of selected tertiary institutions in Lagos State indicated that $14.6 \%$ of the variations in academic staff performance are explained by altruism. It is also showed that altruism has a positive and significant effect on academic staff performance $(\beta=0.3427, t=6.5170, p$-value $=.000)$ and the F-statistic also indicated a high value. Thus, the study rejects the hypothesis that altruism does not have significant influence on the performance of academic staff of selected tertiary institutions in Lagos State

Hypothesis three: Sportsmanship does not have significant influence on the performance of academic staff of selected tertiary institutions in Lagos State

Dependent Variable: Performance

Method: Least Squares

Date: 08/24/19 Time: 17:26

Sample: 1251

Included observations: 251

\begin{tabular}{lrlrr}
\hline \hline \multicolumn{1}{c}{ Variable } & Coefficient & Std. Error & t-Statistic & Prob. \\
\hline \multicolumn{1}{c}{ C } & 3.693450 & 0.199153 & 18.54575 & 0.0000 \\
\multicolumn{1}{c}{ Sportsmanship } & 0.342230 & 0.042157 & 8.117982 & 0.0000 \\
\hline \hline R-squared & 0.209277 & Mean dependent var & 5.291952 \\
Adjusted R-squared & 0.206101 & S.D. dependent var & 0.530170 \\
S.E. of regression & 0.472386 & Akaike info criterion & 1.345897 \\
Sum squared resid & 55.56407 & Schwarz criterion & 1.373988 \\
Log likelihood & -166.9101 & Hannan-Quinn criter. & 1.357202 \\
F-statistic & 65.90163 & Durbin-Watson stat & 1.836921 \\
Prob(F-statistic) & 0.000000 & & \\
\hline \hline
\end{tabular}

The above results indicated that sportsmanship accounted for $20.9 \%$ of the changes in academic staff performance while the remaining $79.1 \%$ were accounted by other variables not considered in the hypothesis. The results further revealed that there is a positive and significant effect of sportsmanship on performance of academic staff of tertiary institutions in Lagos State $(\beta=0.342230, t=8.117882$, $p$-value $=.000)$ with high value of F-statistics of 65.90. The study therefore, rejects the hypothesis that sportsmanship does not have significant influence on the performance of academic staff of selected tertiary institutions in Lagos State

\section{Discussion of Findings}

One of the factors that negate performace today's organization in developing countries like Nigeria is organizational citizenship behaviour. The informal role an employ play on the tasks assign to them to help one another is crucial to their performance. This study had demonstrated that organization citizenship behaviour aid the employee to be effective and efficient in their performance. The findings indicated that the higher the employees' courtesy, altruism and sportsmanship, the higher the way and manner with which the 
employees' will perform well in the tertiary institutions. This definitely, will have a positive impact on the performance of the students and there will be uninterrupted routine activities and this is in line with the human relation theory which emphasizes that employee desire to be part of a supportive team that facilitates development and growth. According to this human relation theory when employee are encouraged or receive support from their colleague, they will be motivated to be more productive which will result to high quality of work. The findings of this study are consistent with the studies of Ejo-Orusa et al (2018); Nyarieko et al. (2017); Zeb and Asia (2016); Shahrouz et al (2016); Lelei et al. (2015); Olowokere et al (2015); Tanaka (2013). However, the findings of the study were inconsistent with the findings of Itiola et al.(2014); Serife (2016); Fatimah et al. (2011)

\section{Conclusions}

In line with results of the study, the study concluded that OCB needs to be encouraged within the academic staff of higher institutions as this would help tremendously on the students' they teach and also promote harmony with the management of tertiary institutions. The study suggested that the management of tertiary institutions in Lagos State and Nigeria as a whole should formulate policies and/or adopt practices that will encourage organization citizenship behaviour for better performance.

The findings of the study are useful to the academic and non-academic staff of tertiary institutions not just in Lagos State but the whole tertiary institutions in Nigeria. Equally, employees from other sector in Nigerian economy could benefits from the findings of the study by understandings how supports they give to each other outside their official obligatory could enhance individual performance towards achieving the organizational goals. Also, the management of tertiary institutions will find the findings of the study to be useful by knowing that the importance of OCB in achieving the stated goals and objectives and this will assist the management to formulate appropriate policy(ies) to foster OCB in their institutions.

\section{References}

1. Cohen, A. \& Vigoda, E. (2000). Do good citizens make good organizational citizens? An empirical examination of the relationship between general citizenship and organizational citizenship behavior in Israel. Administration and Society, 32, 596- 625

2. Ejo-Orusa, H., Gabriel, J. M. O \& Henry, R. K (2018). Organizational citizenship behaviour and corporate performance of telecommunication firms in Port Harcourt, Nigeria. International Journal of Social Sciences and Management Research, 4(4), 20-30

3. Fatimah, O., Amiraa, A. M.\& Halim, F. W. (2011). The relationships between organizational justice, organizational citizenship behavior and job satisfaction. Pertanika Journal of Social Science \& Humunities, 19, 115-121

4. Francis, U. (2012). Organizational citizenship behavior and demographic factors among oil workers in Nigeria. Journal of Huma nities And Social Science,19(8), 87-95.

5. Haque, A., Khatibi, A. \& Karim, K. (2011). Re-organization impact on the telekom Malaysia's international division productivity. Journal of Social Science, 1, 226-231

6. Hardiman, M., Hendra, Y. \& Muhammad, A. (2019). Organizational citizenship behaviour (ocb), and employee's competency to public service quality (Survey at Kantor Kementerian Agama Kabupaten Kerinci, Indonesia). International Journal of Economics, Commerce and Management, 7(4), 814-822

7. Iskandar, M., Ahmad, R. \& Martua, R.H. (2014). Factors influencing employees' performance: A study on the Islamic banks in Indonesia. International Journal of Business and Social Science, 5(2), 73-80

8. Itiola, K.O., Odebiyi, I.I. \&Alabi, E (2014). Empirical study of impact of organizational citizenship behaviour dimensions on job satisfaction among administrative staff of Osun State owned tertiary institutions, Nigeria. International Journal of Academic Research in Business and Social Sciences, 4(8), 264-274

9. Jahangir, N., Akbar, M. M. \& Haq, M. (2004). Organizational citizenship behaviour: Its Nature and Antecedents. Journal of BRAC University, 1, 75-85.

10. Konovsky, M.A. \& Organ, D.W. (1996). Dispositional and contextual determinant of organizational citizenship behavior. Journal of Organizational Behavior, 17(3), 253-266.

11. Lelei, J. C., Chepkwony, P. K. \& Ambrose, K. (2015). Effect of organizational citizenship behavior on employee performance in banking sector, Nairobi County, Kenya. International Journal of Business, Humanities and Technology, 5(4), 55-61

12. Lo, M. C., Ramayah, T. \& Hui, J. K. (2006). An investigation of leadermember exchange effects on organizational citizenship behavior in Malaysia. Journal of Business and Management, 12(1), 5-23

13. Meor, R. A., Rashydan, A., Sabitha, M. \& Nurul, L. (2019). The antecedents of organizational citizenship behavior: A conceptual framework. Journal of Advanced Research in Social and Behavioural Sciences 15(1), 1-14 1

14. Mohammad, J., Habib, F.Q. \& Alias, M.A. (2011). Job satisfaction and organizational citizen ship behavior: An empirical study at higher learning institutions. Asian Academy of Management Journal, 16(2), 149-165.

15. Mohammad, S. I., Saima, A \& Farjana, A. (2016). Organizational citizenship behaviour in public sector: Does job satisfaction play a role. International Journal of Economics and Financial Issues, 6(8), 376-381.

16. Nawaz, N. \& Gomes, A.M. (2018). The relationship between organizational citizenship behavior and team performance: The mediating effect of team conflict. Management and Organizational Studies, 5(1), 15-22

17. Norasherin, B.B., Rohaida, B., Mozhdeh, M., Siti, Z. \& Nor, A. (2016). Strategic use of organizational citizen behaviour a tool for gaining competitive advantage. International Journal of Economics, Commerce and Management, 5(6), 260-274

18. Nyarieko, M.A., Nasusonge, G.S. \& Iravo, M. (2017). Impacts of sportsmanship and altruism on casual employees' performance: Case study of Kenya public universities. International Journal of Business and Management Invention, 6(3), 08-15

19. Olowookere, E.I., Adejuwon, G.A. \& Godwyns A. A.(2015). Benefits of organizational citizenship behaviours for individual employees. Covenant International Journal of Psychology, 1(1), 50-69

20. Organ, D.W. (1997), Organizational citizenship behavior: It's construct clean-up time. Human Performance, $10(2), 85-97$.

21. Organ, D.W., Podsakoff, P.M., \& MacKenzie, S.B. (2006). Organizational citizenship behavior: Its nature,antecedents, and consequences. Sage, Beverly Hills, CA.

22. Poncheri, R. (2006). The impact of work context on the prediction of employee performance. North Carolina State University. Pond, S., Nacoste

23. Robbins, J. (2013). Organizational behavior (15th Global Edition). Upper Saddle River, NJ: Pearson 
24. Serife, Z. E. (2016). The organizational citizenship behaviour of academic staff in North Cyprus. Procedia Economics and Finance, 39, $701-704$

25. Shahrouz, A., Dr. Mahdi, B. \& Marjan, P.(2016). Relation between organizational citizenship behavior and human resources response: Case study: 6 district of Iran gas transmission operations. Mediterranean Journal of Social Sciences, 7(3), 140-151

26. Turek, D. (2015). Human resource management practices influence organizational citizenship behavior? Mediating the role of person organizational fit. Joint International Conference.

27. Yen, H.R. \& Niehoff, B.P. (2004). Organizational citizenship behaviors and organizational effectiveness: Examining relationships in Taiwanese banks. Journal of Applied Social Psychology, 34, 1617-1637.

28. Zeb, J. \& Asia, G. (2016). Factor affecting organizational citizenship behaviour of corporate sector in Bangladesh. European Journal of Business and Management, 7(31), 7-15 